\title{
DATA, EN PROGRESSIV RODEBUTIK?
}

Redaktionelt forord

\section{ASTRID OBERBORBECK ANDERSEN, BARBARA ANN BARRETT, MAJ HEISELBERG OG MY MADSEN}

Hvad er data?

Befinder vi os i en datatidsalder? Og hvad karakteriserer en sådan?

Hvordan former datatidsalderen socialitet og relationer?

Hvilke andre antropologiske spørgsmål dukker op i lyset af en datatidsalder?

Hvad er data, antropologisk set?

Har antropologer og antropologien data? Hvad består sådanne data af, og hvad kan de effektuere?

Hvordan skal eller kan en dataantropologi se ud, og hvordan kan antropologien spille sammen med andre videnskabelige datastudier?

Dette temanummer beskæftiger sig med disse og flere lignende spørgsmål og belyser dem fra forskellige vinkler og i forskellige formater. Når vi i titlen til forordet - på måske lidt klodset vis - spørger, om data er en progressiv rodebutik, favner det to temaer, der karakteriserer temanummeret.

For det første henviser titlen til den proces, hvorigennem temanummeret er blevet til. Tiden imellem foråret 2017, da indkaldelse af artikelforslag til temanummeret Data (Tidsskriftet Antropologi nr. 79) blev offentliggjort, og foråret 2019, hvor vi skriver forordet, mens alle bidrag strømlines og sendes til sats, har til tider syntes som en rodebutik. Redaktionen er blevet reduceret, forøget og igen reduceret; bidrag er blevet leveret, for så at blive trukket tilbage; andre bidrag har forvandlet sig fra ét format til et andet; nogle har slået store analytiske brød op, men har så pludselig trukket sig helt ud; artikler har på forunderlig vis primært været forfattet af studerende eller forskere uden for antropologien og har omhandlet tematikker, som hverken forfatterne eller redaktionen helt har vidst, hvad de skulle gøre med. Og så, i sidste sekund inden temaredaktionen lukkede ned, var der alligevel en del forfattere, der gerne ville nå at have et bidrag med om „data“. Denne ,rodethed“" viser (udover at indkaldelsen til bidrag var bredt for- 
muleret), at antropologien, selv efter at data som fænomen i verden har vundet ny empirisk betydning og mobiliserende styrke, er i færd med at finde fodfæste med sine egne data, forstået som det empiriske materiale, der genereres og/eller undersøges igennem en forskningsproces. Men det vidner også om, at et nyt felt med en mangfoldighed af undersøgelsesobjekter er under udformning i dansk antropologi (og STS) ${ }^{1}$ og i antropologien (og STS) internationalt. Et felt, hvor mange vil være med, men hvor der måske endnu ikke er udviklet et etableret forskningsfelt eller begrebsapparat, som kan guide artikelskrivning for studerende eller for dem, der ikke står ved ,the cutting edge“ af feltet. Som det fremgår af temanummerets indhold, er ,data“ et felt i progression: forskere bliver ansat, diskuterer, optager positioner, interviewer hinanden, formulerer feltets udvikling, nøglepersoner, aspirationer og kritiske problematikker - samtidig er det dog påfaldende, hvor mange bidrag til temanummeret der ikke er i det gængse ,jeg-harfundet-ud-af-noget"-artikelformat. Det er, som om alle vil være med, men samtidig også skal føle hinanden og datafeltet på tænderne. Dette nye felt af antropologiske (og STS-orienterede) datastudier i Danmark er dog alligevel blevet godt repræsenteret $\mathrm{i}$ dette temanummer, og vi håber, at nummerets bidrag vil være informative udi denne progressive datarodebutik.

Dette leder os til den anden betydning, som titlen henviser til, nemlig den måde, data opstår eller dukker op på igennem de forskellige bidrag. Hermed vil vi ikke antyde, at bidragene, hver for sig eller samlet set, er upræcise eller præget af rod; tværtimod. Bidragene kommer på forskellig vis med meget klare forslag, tilgange og begreber til at konkretisere, hvordan antropologer og STS'ere kan arbejde med data og big data. Forslagene og tilgangene er klare, men „data“ i sig selv, som det skrives frem på tværs af bidragene, fremstår som et mangfoldigt, flertydigt og tvetydigt fænomen - en rodebutik. Dog er det helt klart, at „data“" er vigtigt at få greb om som fænomen og begreb, om det så er data som de kropslige og følelsesmæssige erfaringer, som den etnografiske feltarbejder oplever (Hansen \& Gudmundsen; Moltke), etnografiske data til kommercielle formål (Pedersen), data som sansende og seende (Møhl), data som indgang til en kvantitativ, beregningsbaseret antropologi (Andersen; Breslin), data i shamanistiske ceremonier og materielle rammer (Sjørslev), eller om det er data i gener (Svendsen), data som smukke, rå og beskidte (Høyer \& Winthereik), koloniale og statistiske (Christiansen), befolkningsdata eller statistikker over hjemløse i Europa (Winthereik et al.) eller metadata og digitale spor, der efterlades af „sociale“ big data (Madsen \& Schyberg). Måske netop fordi „data“ er lidt af en rodebutik, er det et begreb og en mangfoldighed af fænomener med mange muligheder og retninger for analytisk progression. 


\section{Data i en datatidsalder}

I indkaldelsen til temanummeret inviterede vi forfattere til at beskæftige sig med data bredt, på forskellige måder og igennem forskellige fagligheder. Vi ønskede at inkludere og belyse nye tilgange til og forståelser af videnskabelige data. I antropologien bruges ordet „data“ sjældent (men dog måske i tilbagevendende og stigende grad) til at beskrive vores materiale fra felten. Vores hensigt med at åbne debatten om dette begreb var at udvide rammerne for, hvad dette materiale kan bestå af. Vi lagde op til at forstå data som alt det, der på den ene eller anden måde er blevet genereret og indsamlet, og som i kombination med teori og analyse kan fortælle os om den sociale verden. Temanummeret søger derfor at belyse nye måder at forholde sig til data på. I en paradigmatisk forstand: Hvad gælder som data og hvorfor? I en mere praksisorienteret forstand: Hvad kan forskellige typer data vise os? I epistemologisk forstand: Hvordan kan vi erkende data og skabe viden om data? Hvilke former for viden om data kan betragtes som antropologisk? Og i ontologisk forstand: Hvad er data, og hvad effektuerer eller gør data? Hvordan er dataforskning indenfor antropologi og STS med til at skabe dataverdener og forme datatidsalderen?

Alle bidrag i temanummeret synes at være enige om at tage det som præmis, at vi befinder os i en datatidsalder, og at denne er karakteriseret af, at dataanalyser af utømmelige mængder af data florerer og skaber entusiasme og håb (og nogle gange uro) blandt mange forskellige slags aktører. Det er et billede af en datatidsalder generaliseret af datahype og længsel mod „det datadrevne samfund“, hvor mere data er lig med større præcision, større sandhed (Pedersen), og hvor data høstes som „det nye guld“. Samtidig fremhæver flere af temanummerets forfattere, at datatidsalderen og big data også fremprovokerer spørgsmål om ansvar og ansvarlighed (Winthereik; Breslin). Hvem stilles for eksempel til ansvar for de uligheder, som big data og algoritmer integrerer og forstørrer i datadrevne processer? Denne tidsalder, med dens mange forandringer, fordrer og muliggør en omkalfatring af antropologien. De forskellige bidrag lægger tilsammen op til, hvordan antropologi som uddannelse, metodisk og analytisk kan foretage en sådan omkalfatring. På den ene side kræver det nye tilgange indenfor antropologien, og at antropologien indgår i nye konstellationer og samarbejder med andre discipliner (Svendsen). På den anden side kræver det, at antropologien holder fast ved spidskompetencer som etnografi, informantsamtykke og indlevelse $\mathrm{i}$ andres sociale liv (Breslin).

De forskellige bidrag er skrevet ud fra empiriske studier i meget forskellige etnografiske felter. Disse spænder fra kommunale ledere og sundheds-IT i Danmark, udvikling af teknologier til vedvarende energi og Big Tech-datacentre; databeskyttelse og EU's persondataforordning (GDPR) til Bell Curve-guddom- 
melighed blandt datalogistuderende i Singapore og biometriske overvågningsteknologier, der arbejder sammen med europæisk politi og grænsevagter - blandt andre. Den empiriske tilgang viser, at den antropologiske tilgang til datahypen kan og bør være kulturspecifik, men samtidig peger bidragene i dette temanummer også på spørgsmål, som går på tværs af alle de specifikke felter.

\section{Hvordan skriver og griber antropologer „big data“?}

Flere af temanummerets bidrag nævner fænomenet og begrebet „big data“. Læseren vil notere sig, at der er forskel på, hvordan forfatterne skriver fænomenet frem, med store eller små bogstaver, med anførselstegn eller uden: Big Data, ,big data“, „Big data“, big data eller „Big Data“. Disse måder reflekterer, mere eller mindre bevidst fra forfatternes side, en stor forskel på, med hvilken (antropologisk) tilgang forfatteren går til fænomenet. Nogle kontrasterer ,big“ med „thick“, hvilket refererer til Clifford Geertz' „thick description“ (1973), og fremhæver, som eksempelvis Svendsen om sit samarbejde på tværs af fakulteter og institutioner, at antropologi kan bidrage med dybde, nuancer og konsistens (fede data) og således komplementere eller endog forbedre andre dataformer (Møhl). Et sådant standpunkt fremhæver antropologiske dyder, som vi kender dem: kvalitativt baserede, dybdegående og nuancerede bidrag, der bringer nødvendige og usete vinkler frem i lyset-især indenfor en kontekst, der favoriserer kvantitetens logik: store mængder og sammenføring. Andre tilgange forsøger at skubbe antropologisk praksis i retning af en ,maskinel antropologi“, hvor antropologien skal omskoles og omstille sig, både metodisk og analytisk, til at kunne arbejde med store mængder digitale data og med dataloger som samarbejdspartnere. Dette kræver nye metoder og andre færdigheder såsom softwarehåndtering, kodning og digitale visualiseringsteknikker, hvormed ,big data“" kan håndteres antropologisk (Madsen \& Schyberg). Dette er computerberegning som et udgangspunkt for en antropologisk praksis, der følger og arbejder med computerberegningens præmisser. Det er tydeligt i temanummerets bidrag, at datatidsalderen ikke kun er en brydningstid i verden, men også er det i antropologien såvel som i andre videnskaber og for forfatternes videnskabelige praksis. Denne brydningstid er karakteriseret af nye genstandsfelter for antropologisk og tværfaglig forskning samt nye datakombinationer og formater for samarbejde, der er absolut nødvendige for at kunne fange ,big data“ ind og arbejde med det.

Men ikke alle temanummerets bidrag handler om digitale data og data i store mængder. Emner, der giver genlyd på tværs af typer af data, er datadeling - både i projekter, hvor antropologer samarbejder (Gudmundsen \& Hansen), og i interdisciplinære projekter (Madsen \& Schyberg; Svendsen). Det er spørgsmål om, 
hvordan data skal opbevares, og hvordan data bliver formet af den måde, de bliver indsamlet, opbevaret og delt på (Christiansen; Albris; Svendsen). Det er også spørgsmål om kropslig erfaring, sansning og kropsliggørelse i forståelsen følelser og kropslig erfaring som etnografisk data (Moltke) og som teknologiske kroppe, der kan sanse, se og overse (Møhl) - hvordan kan og skal sådanne etnografiske data, deles, præsenteres og håndteres, både analytisk og på etisk vis?

Etik og tillid er temaer, der ligeledes går igen i flere bidrag; etik i antropologi og spørgsmålet om datadeling, hvad enten det er persondata eller etnografiske data, der er tale om. Spørgsmålet om, hvordan man overlever som antropolog og arbejder etisk forsvarligt med etnografiske data i en post-GDPR-kontekst (Albris); spørgsmålet om det etiske ved dataskabelse og forholdet mellem mål og metode i arbejde med forsøgsdyr (Svendsen); og spørgsmålet om tillid mellem samarbejdspartnere i et etnografisk feltarbejde, hvor data og fortrolige oplysninger deles (Gudmundsen \& Hansen). Uanset hvilken form for data der er tale om, fungerer data som bevismateriale og indgår $i$ et legitimeringsarbejde (Madsen \& Schyberg; Pedersen).

\section{Kære læser ...}

Slutteligt, inden læseren går i kast med temanummerets bidrag, må vi forklare, at „rodebutikken data“ også kan forstås som den umiddelbare beskrivelse af arten og variationen af bidrag til dette temanummer, der indholdsmæssigt ikke er karakteriseret af den klassiske struktur, som indholdet i Tidsskriftet Antropologi oftest har, hvor artiklen spiller den dominerende rolle. Dette nummer adskiller sig ved, at bidragenes form spænder vidt; over tiltrædelses- og afskedsforelæsninger, over portræt- og interviewartikler og en håndfuld positioner - og kun et par af de mere klassiske artikler (som måske alligevel ikke er så klassiske endda). Men „rodetheden“ er kun umiddelbar, da bidragenes variation netop afspejler, at feltet af tilgange til data hverken er stabilt eller fuldt ud etableret. Én af de centrale pointer med dette temanummer er derfor ikke at afvise forskellige former for data og forståelser af data, men at se dem som en mangfoldighed af, hvordan data som fænomen kan forstås og begrebsliggøres i et bestemt historisk øjeblik. En anden pointe er at give læseren mulighed for at udforske, hvilke perspektiver forskellige typer data tilbyder at åbne op for, og hvordan både verden og antropologien kommer til syne igennem disse perspektiver. Kære læser, bedøm selv, hvorvidt "data er en progressiv rodebutik“.

God læselyst! 


\section{Note}

1. STS står for „Science and Technology Studies“. Når vi i dette forord gentagende gange tilføjer parentesen , ,(og STS)“ ved siden af ,, antropologi“, er det, fordi forskningsfeltet STS og antropologien deler slægtskab i forhold til de metodiske og analytiske tilgange, hvormed forskere fra de to felter undersøger data. Desuden definerer en del af forfatterne i dette temanummer sig lige så meget som STS'ere som antropologer, hvilket fremgår i de respektive bidrag. 